\title{
How Do We Look?
}

\section{JOHN PEFFER}

Ramapo College, USA

https://orcid.org/0000-0002-6244-952X

\begin{abstract}
In South Africa under apartheid, portrait images displayed in private homes emphasised the dignity of their subjects and the stability of family life during a period of indignity and social upheaval. But when interviewing families about them, one often encounters sensitivity issues of the sort too often passed over by scholars and curators who valorise studio practices without consulting the actual subjects of the images. These include a range of anxieties about repackaging for display in new contexts and for broader audiences, as well as basic copyright and authorship concerns in common with other African and 'family' photographies. The particular anxieties themselves speak to the local histories of how these self-images were used and lived. This essay argues for a closer consideration and a new ethics for looking at and writing about these pictures. It is based on research since 2010 on family collections of photographs in South Africa's Black urban neighbourhoods.
\end{abstract}

I thus am able to conceive of the opacity of the other for me, without reproach for my opacity for him. To feel in solidarity with him or to build with him or to like what he does, it is not necessary for me to grasp him. It is not necessary to try to become the other (to become other) nor to 'make' him in my image.

\section{Édouard Glissant, 'For Opacity’}

In 2010 I was speaking with my friend Mpho Mathebula in Senaoane, Soweto. ${ }^{*} \mathrm{He}$ had assisted in the research for my book Art and the End of Apartheid, ${ }^{1}$ where in the last chapter I had retold a common story about South African photographic history: there were colonial images that subjugated and exoticised indigenous people, there

* Dedicated to my dear friend and collaborator Mpho Mathebula, who, during the course of our research together died suddenly of an unspecified illness in 2015, and to Santu Mofokeng, my touchstone, intellectual guide, and comrade of over 25 years, who passed in 2020. This essay is based on research since 2010 in South Africa, supported by fellowships and residencies at the Metropolitan Museum of Art, the National Endowment for the Humanities, Fulbright, American Council of Learned Societies, The Clark Art Institute, Columbia University Institute for Comparative Literature and Society, Wits Institute for Social and Economic Research, and the Department of Visual Art at the University of Johannesburg. Special thanks to Patricia Mabusela, Senzeni Marasela, Charles Palm, Nikolas Zimmer, Giulia Paoletti, the Koko family, Thabo Rapoo, Katelyn Chetty, Khethiwe Matshana, and Sandra November Williams, and two anonymous reviewers.

1 J. Peffer, Art and the End of Apartheid (Minneapolis: University of Minnesota Press, 2009). 
was a bureaucracy that falsely categorised the population according to ethnic and racial types for purposes of labour control, there were documentary images that exposed the bodily and institutional violence of the state, there were the liberated voices of artists no longer constrained by commitment to classic documentary modes. There was something missing. I was not sure what, and that is what I was discussing with Mr Mathebula. I remember his deadpan answer as both a cut and a catharsis. He told me he and his friends who were young men in Soweto during the struggle years never saw any of the famous documentary images from the 1970s and 1980s, at least not until many years later. 'Why didn't you ask us about our own photographs?' he chided, and he brought out his parents' family albums, saying 'this is what photography was, for $u s$. With this friendly upbraiding I was determined to listen and to look more carefully. With Mathebula's help, and later also with Patricia Mabusela, we began to search for whatever kind of people's history might be divined from these pictures.

Here was something that could be shared as a positive story with the wider world and as an antidote to overdetermined images of Black bodies-as-spectacle. Here was a means to marshal the quotidian against a culture of surveillance. Here was a practice of photographic self-determination that was acting as a kind of refusal of the conditions people were forced to live in. But I also began to notice that as often as people welcomed me into their homes to share their pictures - and these were mostly my friends, and those introduced to me by Mathebula and Mabusela, as well as their extended families and their close neighbours - there were others who were wary of strangers handling their family pictures. Most of these people were happy to share their stories, but they were also reluctant to have their pictures of their parents or children, however positive looking on their surface, floating about in the world.

Over time I found these requests for opacity kept accumulating in my notes. Sometimes they were oblique, sometimes more pointed. I began to think of them together as a kind of litany of refusal that differed from the literal content of the images themselves.

In South Africa, people's reasons for not wishing to share their family photos with the wider world may be related to the traumas caused by disruption of family life and the psychic degradation that came from living under a racialised state: broken families, alcoholism, marital violence. Concern that some foreigner would make money or a career off their faces, without giving them their share, was another factor. Belief in a spiritual efficacy of images, also sometimes in play, was mentioned to me less often than the basic desire for privacy over intimate lives and control over the uses of their likeness. While explanations for reservations vary widely, they all speak to the individuality of lives as lived and the processes of subject creation at the intersection of photographic imaging. It struck me that this was a common characteristic of family photography everywhere, and despite its 'in plain sight' aspect it had not been fully accommodated in the literature. Thinking about refusal can be a way to explore the texture of experience on the micro-historical level, while honouring the dignity subjects claim through their personal creation and collection of images of themselves. To approach photography like this is to understand that its 
images do not merely illustrate the lives of subjects, but rather that subjectivity (and subjection) are themselves created by, lived through, and contested in what subjects make of their images.

In this context it is important to acknowledge the predatory implications of the current art market vogue for an 'African photography' that often includes the kinds of images that scholars and indeed the general public in another context might refer to as private images, as 'family photography'. It was by working with family collections in South Africa that I came to realise that many of these pictures in the galleries actually belonged to the people in the pictures. In South Africa most of the snapshots, studio pictures, and painted enlargements found in homes together also constitute a 'family photography' because they were produced for, held by, and helped to selfdefine the family. ${ }^{2}$ Therefore, in this essay I am making the case for considering the family, and individuals within extended families, as the site of authorship and the creator and owner of the archive. By reframing African photography as family photography, an ethics of looking and display should follow. I propose further that not only do these pictures help construct an ideal family, but they are or were once part of families, and it may be useful to treat them as if they are from our family: to honour, to respect, to hide away, or to self-consciously reveal as we do with our own. It is not just about the right to be looked at, to be regarded with interest or empathy; it is also about the right to privacy, the right to be let alone.

Photography in Africa has not only been about the creation of positive or aspirational images during times of hardship, but also about establishing control over one's own image in other ways. The definition of boundaries and networks that constitute the self are at stake when considering photographs as family, and that is my reason for making a case for privacy, for opacity. In this I am elaborating from (and enacting) philosopher Édouard Glissant's idea, when he says that allowing for an opacity of ourselves to ourselves as well as respect for the opacity of others may facilitate more open forms of human relation. ${ }^{3}$ Is it possible to engage thoughtfully with a subject without the ultimate object being to know everything? Is it possible to develop new approaches to researching and writing that allow for and engage with people's desires for obscurity? In response to the current market for studies, collections, and exhibitions of African photography, I would like to pause to ask what those in the pictures themselves might think about it.

While mindful of the fact that images almost by definition get away from us, I am interested in developing decolonial strategies for rethinking such popular and private image-object forms as the global art market attempts to repackage and coopt them as commodities. If we are considering how images move promiscuously across media and markets, we should also consider how this may occur along particular social-political-economic vectors and thus not forget it also implies a mode of responsibility. What do we owe the image? Or its subjects? Such questions have

2 In this approach I am inspired by the work of Thy Phu and colleagues at the Family Camera Network, http:// familycameranetwork.org/. See also D. Willis, Picturing Us: African American Identity in Photography (New York: The New Press, 1994); and J. Spence and P. Holland (eds), Family Snaps: The Meanings of Domestic Photography (London: Virago, 1991).

E. Glissant, The Poetics of Relation, B. Wing (trans.) (Ann Arbor: The University of Michigan Press, 1997). 
increased relevance in light of current debates around restitution of cultural works that were removed or altered under unequal relations of power, and their changing status as diasporas of images.

\section{A Litany, for Opacity}

My friend S October grew up in a village outside Cape Town, founded in the nineteenth century as a missionary refuge for freed slaves from the surrounding wine estates. The area today has a mixed heritage that includes South East Asia, Africa, and Europe. A few years ago we were talking about the small-town experience of photography, and he introduced me to his aunt, Mrs C_ who worked as a docent at the local history museum. There, standing in a gallery filled with hand-tinted enlarged wedding portraits donated by prominent community members, I asked about her own family's portraits. That is when she told me about 'the two Betties'. It seems her grandmother 'had always favoured cousin Bettie', because she was born fairer in complexion than her brother and sister. Only Bettie's portrait was hung in the house. There weren't any pictures of the other grandchildren on display. Actually, there were two Betties. Two portraits, I mean. Both had been ordered in the 1970s from Peninsula Studios, an enterprise that was popular in the communities around the Cape where it had cornered the market in hand-coloured enlargements of family snapshots. The grandmother had given a child snapshot to the visiting salesman from Peninsula, asking that a painting be made from it. But when it was returned, the portrait upset the grandmother because she thought it was shaded too dark. A second portrait was commissioned, this time with instructions to 'make it whiter.' The 'black one' was hidden away. But one day as the children were helping clean the house, they found her on the floor facing the wall behind a chair. The existence of black Bettie remains an open secret in the family, a story retold and possibly embellished, but with some unease. When I asked if I could see the pictures, I was told they were not available, possibly misplaced. In any case, it was probably best they be kept within the family since there were ongoing 'complications regarding trust' amongst some members. I was told it was okay to share this story, but, as I do throughout this essay, I have altered or obscured certain names and details for privacy sake. Also, as with most other individual stories shared here, 'the two Betties' exemplify a wider trend. Among those in the historically called 'coloured' communities whom I interviewed in the Cape one thing that was very commonly spoken about was a desire, when having their photographs developed or retouched, that they 'come out whiter'.

Another acquaintance, $\mathrm{R}$ , said he was puzzled growing up because there were two wedding portraits of his parents hanging in the house, but they did not look the same. The family had lived in Durban for several generations and was originally from Southern India. Only as a teenager was he informed that the father had actually had two wives and his older sisters were really half-sisters. In the 1940s the father had been a ballroom dancer, and one year while on tour in Cape Town he met another dancer, a 'coloured' woman, and they fell in love. They married, moved to Durban, and had two baby girls. But his family never approved, demanding the 
girls straighten their hair and be given Indian names. Esme became 'Sita', and Lindi became 'Siruvani'. When the girls were two and four years old, the mother died, and the father remarried, this time to a 'proper Indian girl'. The family rarely spoke openly about this, only telling the children about the portraits, 'those are both your mother'. The father and second mother are recently deceased, and it was best not to share these images, I was told, at least not until the family works things out amongst themselves.

Demands for respect and for the right of refusal run the gamut from a desire for anonymity, or simple pride, to heavier instances of so-called illegitimacy, embarrassment at one's ancestry, and related forms of internalised violence that are common in certain historically traumatised communities. As historian Dr Isaac Balie told me: 'You know this thing about families who split up because of the reclassification. My dad warned us: "don't greet your cousins, hey, because they are now white. You may insult them." So families were split up. They even changed their surnames. In my family, for example, those who looked more European changed their surname to Bailey. We who would not pass, who look more African, stick to Balie, b-a-l-i-e.4 Dr Balie was telling me about his curatorial work on a genealogy exhibition in the Western Cape mission town of Genadendal, where he displayed portrait enlargements that had been stored in attics and side rooms, to try to break down negative racial thinking that was ingrained in the community. To explain the context, he told this personal story: 'While working on that display, [he was cleaning] some of [the pictures that had become infested with] crawling insects. When [cleaning one portrait], [he found] another picture folded behind, against the [backing].' '[Suddenly] This whole thing was revealed to me,' Balie told me. 'This was a family secret. Born in the month of April, he got the surname "April". He was illegitimate of a white farmer, who did not want him to get his surname. I [later discovered] this farmer never had any children with his actual wife. When that family passed on, they never left children, except for this [man] - and he got that picture. This kind of illegitimacy was kept secret in many families. It was not a thing to talk about. Especially in the church context, it was not a nice thing, it was kept secret. Then I went to the register and the missionaries had put the farmer's name in brackets. They knew. But it was not something for the public.' Experiences like this were common in his community, he said, and for many the past is too painful still. 'So [even in their own homes, people there] are more interested in putting up pictures of their own children.'

For reasons like these, many of the people I spoke with preferred that their personal photos not be spread around, because beneath their otherwise innocuous appearance these images covered over a still simmering memory of trauma. Traumas of domestic violence, alcoholism, teen pregnancy, disruptive race classification and generally degraded living conditions that resulted from colonialism and then apartheid have led in some places to a kind of structured forgetting or structured denial as a survival strategy, a wish to bury the past, to not be reminded even by images that seem neutral on their surface. For comparison we can look to the work of Heike 
Behrend, where in her study of photography in East Africa she claims that the popularity of street-corner portrait studios - whose imagery was idealising if not fantastic - was an assertion of the right to control the picturing of the self in a society where most people are voiceless and impoverished. She notes that in recent public representations of biographical photos used for Christian funerals in Kenya, images are not included if they date to the period of extreme political violence suffered during the 1950s 'war of independence' between the British and so-called Mau Mau insurgents. ${ }^{5}$ Her implication is that even if they had seemed innocuous on the surface in their imagery, images from that period might trigger negative associations.

Photographs will be hidden away and others are cherished, and it is difficult to ascertain which will be which and when this might change from the picture on their surface. One of the first pictures shared with me was in Meadowlands, Soweto, in 2010 by Ms J who was introduced to me by my old friend, the artist and tavern owner Agrippa Nhlapo. She was a teenager, an HIV orphan, and single mother, and she proudly showed me an image of her grandparents who had lived in the famed mixed-race neighbourhood of Sophiatown before being forcibly removed to Soweto by the apartheid state in the 1950s. She showed me this picture which she kept wrapped in plastic under her bed, on condition that I promise 'not to take them off to a museum or something' since they are the only thing she has left to remember her family by. Her elderly neighbour told me she herself had no pictures to share. She destroyed everything after her husband passed away in 1990. Theirs had been a love match', she said, and now that he was gone she could no longer bear to see his face or them together in pictures. Another friend's cousin threw out her husband's photographs when he passed. 'It was an unhappy marriage, she said, declining to say more.

Marriage trouble may surface within the family album. In 2014, in KwaZuluNatal in the hilly countryside outside of Empangeni, Mathebula and I were invited to visit a household of almost all women who are part of the iBandla lamaNazaretha community. Unusual for a rural area where most people owned only a few if any photographs, these women kept two whole albums filled with dozens of images dating back to the 1960s. The albums are an invaluable record of the nodal network of studios that dotted the small Natal towns in those days and the places that people travelled to and from. They also preserve what local people deemed important to record of their lives, and changes in styles of personal adornment. Especially during the 1970s and 1980s travelling into town was sort of a fashion show for them, and they frequented the photo studios to document their outfits and beadwork they had made for sale. Looking over this picture collection I asked about particular ones that struck my eye. That is how we discovered that the husband (who was not there in the room with us) had inserted photos of his other, younger girlfriend into the family album. A heated conversation ensued. It is a polygamous community, but the husband had 'not paid lobola' for the new girlfriend and there was some tension among the other women of the house about this. Any outside observer examining

5 H. Behrend, “'Celebrating Life”: The Construction of Photographic Biographies in Funeral Rites among Kenyan Christians', in C. Morton and D. Newbury (eds), The African Photographic Archive (London: Bloomsbury, 2015), 87. 
this collection would only see beautiful examples of small-town studio portraits and people displaying their valuable beadwork. Nevertheless, the women requested I not share the images of the girlfriend.

Even when images are saved and are willingly shared, by whom and under what conditions is important to consider. For instance, in 2012 Patricia Mabusela introduced me to her aunt Gladys in Chiawelo who showed us a snap of herself taken in 1971, which she saved in a shoebox filled with keepsakes of relatives and friends. It was made 'as a remembrance', she said, 'of a new two-piece suit I had just bought at John Orrs', the department store in Johannesburg. ${ }^{6}$ This she proudly said I may share in my writing. But if the DKoko studio in Tladi where the picture was made were to sell other copies from the negatives that they kept on file, she would not approve.

Derrick and Naomi Koko were the proprietors of DKoko studios in Tladi, Soweto, from the 1960s through the 1990s. They are now deceased, but I asked their daughter Tebogo about the possibility of selling their clients' photos and she insisted her parents would never have thought of handing over to strangers any copies of people's photographs whose negatives had been kept on file in the shop. ${ }^{7}$ Further research confirmed that this was the general attitude in both urban and rural Black communities. Other scholars have also noted a concern for customers' ownership rights, such as was made explicit by Daniel Morolong, the East London press photographer and portrait studio owner who donated his archive to researchers in 2001. According to Bank, Qebeyi and Patterson in their book on this archive, Morolong stated at the time of his gift that his photography 'did not belong to him personally but to the community as a whole because they "were the ones who asked me to take the shots and they also paid me to develop the images in my studio"'.

It therefore merits underscoring that the potential giving or selling of customers' photos to strangers would have been considered aberrant during the heyday of studio photography in South Africa from the 1950s to the early 1990s. There was even a threatening implication in the A-frame boards and the window displays for camera shops in town where examples of photos were shown. During a discussion about the street portrait photographers who used to haunt the main shopping districts in downtown Johannesburg in the 1950s, 1960s, and early 1970s, Santu Mofokeng recalled to me, albeit with humour in his voice and a spark in his eye (as if to say that not everyone was overly anxious about this): 'This was almost like blackmail! I see you dressed nice, I snap you. If you don't come and buy the picture, I put it in the window. Because of the attitude toward photography, you don't want ... You don't ask to be photographed, they just jump out at you with a tab number.'

Mpho Mathebula and I had heard something similar in rural KwaZulu-Natal, from many of those, like the women mentioned earlier, who had their portraits done at studios in the nearby towns from the 1960s to the 1980s. These were mostly teenage

\footnotetext{
Interview with Gladys Tau Selwane, by John Peffer and Patricia Mabusela, Chiawelo, 3 August 2012. Interview with Tebogo Koko, by John Peffer and Patricia Mabusela, Tladi, 30 January 2013.

L. Bank, M. Qebeyi and M. Patterson (eds), Imonti Modern: Picturing the Life \& Times of a South African Location (Cape Town: HSRC Press, 2018), 11.

Interview with Santu Mofokeng, Bez Valley, 13 January 2013.
} 
women and men who dressed in their finest beadwork for the camera as part of their courtship or as they were preparing for marriage. But going for snaps in town was also an event in itself, a thing to do with friends and a form of bonding. Image processing took a few days, and we were told that on occasion people would go just for the fun of posing, never intending to collect their images later. Certain studios were located near taxi ranks, and people heading out of town might find themselves unable to return to collect their pictures. Sometimes one could not afford to pay. But if they neglected to return or to pay in full, the image would be placed in the front window of the shop as a sort of gallery of shame. According to Mrs Situsile Cele, the local Zululand Studios used to do this, and she and her friends feared that these photos might be 'sold to other people who could use them for other, sinister, purposes. ${ }^{10}$ The young women she knew when growing up in the 1970s were especially unnerved by the prospect that some stranger, some man, might choose to buy their picture from the window and, as she said, 'put muthi on it' to seduce them.

A general concern about your pictures getting into the wrong hands may intersect with spiritual beliefs or anxieties about sorcery. As Adam Ashforth found in his study of 'witchcraft' in South Africa, many claim it is possible that a photograph could be used in sorcery but there was not a consensus among those he interviewed since, 'As with uses of muthi, although everyone knows that images of persons can be used to powerful effect, few can say exactly what can and cannot be done with pictures, nor can they specify how. ${ }^{11}$ Ashforth, who lived during his research in Mapetla Extension, Soweto, tells of a friend who, when seeing his photo collection of other Soweto people, remarked that 'a Black' would not normally keep a collection of pictures of other people like this. Ashforth states this is because, 'Images can be used for nefarious purposes. They can be used to kill the person pictured. They can be used to enslave people. They can also be used to make a person fall in love, regardless of her own desires. ${ }^{\prime 2}$ A sangoma or inyanga could perhaps use a photograph like an ID picture to show to a client's ancestors, to help them identify a person, and then muthi may be applied as 'the agent of the ancestor's wishes. ${ }^{13}$ Ashforth found that even people who are otherwise not concerned with African traditions on a daily basis could still be quite fearful if a photograph of them were in the hands of someone who wished to do them harm. He relates a story about his friend who was desperate to retrieve pictures of himself that he had given a girlfriend he had jilted, whose mother had become a sangoma. ${ }^{14} \mathrm{He}$ also makes clear that it is not a concern for most that the act of having their picture taken might result in their 'soul being stolen. ${ }^{15} \mathrm{My}$ own research also bears this out, as does the direct evidence of the thousands upon thousands, indeed, the generations of studio snaps that African people have had made of themselves since the late nineteenth century. Photographs made for oneself

\footnotetext{
0 Interview with Situsile Cele, by John Peffer and Mpho Mathebula, Empangeni, 24 July 2014.

A. Ashforth, Witchcraft, Violence, and Democracy in South Africa (Chicago: University of Chicago Press, 2005$), 231$. Ibid.

Ibid.

Ibid., 231-2.

Ibid., 232. See also Z.S. Strother, “A Photograph Steals a Soul”: The History of an Idea', in J. Peffer and E. Cameron (eds), Portraiture and Photography in Africa (Bloomington: Indiana University Press, 2013).
} 
were enormously popular; they were not generally feared, not in South Africa. All the same, as Ashforth found and my own research confirms, pictures of the dead, whether in a funeral programme or in a family album, are usually either destroyed or 'carefully stowed and accounted for.' ${ }^{16}$ Without denying that images may have spiritual efficacy in some manner, the problem is not the image or the technology itself but what someone else might do with it.

Muthi or not, the practice of placing unpaid pictures in the store windows is something I was told about repeatedly as characteristic of the experience of photography - in Marabastad, in Johannesburg, in Soweto, in rural towns - enough to suggest this was common practice. Yet despite concerns being voiced, I never heard of any photographer actually selling or even giving their clients' images to strangers, at least not until the 1990s when local demand for studio images declined and the international art market began to take an interest in these otherwise personal uses of photography in Africa. I surmise that doing so earlier on would likely not have been good for business, since that would be going beyond the pale, as it would surely indicate to future paying clients that such a photographer could not be fully trusted with their or their loved one's image.

In The Gambia, Liam Buckley found that, 'The public profile of the photographer aligns him with the value of saay-saay - shamelessness':

The photographer is saay-saay; he is careless of social rules. The term usually refers to well-dressed hooligans, street toughs, louts, and urchins. It is the cockiness and street smarts of these characters that is carried over when saay-saay is used in the context of appearance and adornment ... The saaysaay man is not shy (ruus). He has money and good clothes - although how he acquired them is subject to some speculation and suspicion ... The studio celebrates the ethos of saay-saay. ${ }^{17}$

Buckley's research indicates that at least in The Gambia, if one looks more closely, 'The shamelessness of the portrait photographer places him in a realm closer to that of a trickster than a praise singer.' ${ }^{\prime 18}$ This resonates, at least in part, with Mofokeng's comments about 'blackmail', the placing of customers' pictures in the window against their wishes, and the very real concerns about trust that some patrons had vis-a-vis their photographers, and it therefore merits closer analysis.

In South Africa before the 1990s, Black photographers were set apart from their neighbours in the sense that theirs was one of few professions where one did not need to work for white people. Black photographers did not wholly depend upon the political economy of apartheid subservience just to earn a living. Black photographers were therefore more independent than many others around them. They did not necessarily have to 'go to town' or to the 'white suburbs' to find employment.

16 Ashforth, Witchcraft, 234.

17 L. Buckley, 'Portrait Photography in a Postcolonial Age: How Beauty Tells the Truth', in J. Peffer and E. Cameron (eds),

Portraiture and Photography in Africa (Bloomington: Indiana University Press, 2013), 305.

Ibid., 306. 
Also, like other relatively more independent professionals, including school teachers, nurses, preachers, and traditional healers, photographers were change agents; they helped improve you. Portrait photographers are not traditional healers, izinyanga or izangoma, and they are not ministers. But because they may help improve your image they are change agents of a visual sort and in that way they are also like healers. This was the offer made explicit in the motto for the KwaMadiba Nkosi studio in Mofolo North in the 1970s: 'Izithombe Ezixolisayo', that is, that the images made of you could apologise for your faults, make you look good, make you feel good, and put you at peace. ${ }^{19}$ A certain level of trust, a social compact (whether stated outright or not) should be understood to have been in play between photographers and their clients. Being like a healer therefore comes with a like responsibility to not abuse your skills for antisocial ends.

In 2014 Mathebula and I met Mr Miki Moeketsi at Voti eatery in Phiri over chicken stew and pap. Moeketsi is now an older man, retired and living in Diepkloof, Soweto. ${ }^{20}$ But as a young man during the 1970s he had a 'spare time' business as a roving neighbourhood photographer. Mr Moeketsi would not show me any images of himself as a young adult, saying he could no longer bear to look at them because as he said (though he claimed he was 'not nostalgic') he and some of his comrades are 'embarrassed by what they are now. Those old pictures only reminded them that they were 'not beautiful like that any more'. Conversely, this sentiment reminded me of other elderly people, now quite conservative in their lifestyle, who today are church pastors or choir members or otherwise respectable citizens in their neighbourhood. These same people led wilder lives during their youth and would often have snaps of themselves taken, at drinking parties, or with lovers, by neighbourhood photographers like Mr Moeketsi. They were usually happy to share these old photos with me, yet they preferred that they did not circulate too widely, since it might dishonour the families' reputation. ${ }^{21}$

I asked Mr Moeketsi about these types of snaps that he had made for hire at parties where people sometimes acted out. Did he have any examples from his 'archives' that I could see? He replied that he could not show other people's photos because he usually gave the negatives, too, when he sold the pictures, since that is what his customers requested. In any case, for the others, he said, 'I do not have their permission to show. ${ }^{22} \mathrm{He}$ did tell me about a favourite photograph of his own, the first one of him that he could remember. It was taken by a photographer in Soweto in the early 1950s, when he was six years old. It is a snap of him with his mother outside their house. 'She worked in the white suburbs,' he said, and he would 'sometimes go two or three

19 My gratitude to Senzeni Marasela for translation help with this idiomatic expression. The motto is in isiXhosa, and it seems the stamp maker made a typo by spelling what should be izithombe (image, figure, copy, photograph) as izithombo (seedling, young fertile growing thing). See also Ashforth (Witchcraft, 235-6) for a discussion of the meanings of izithombe in isiZulu, which likewise include images with generative capacity including idols, photographs, or 'a child that strongly resembles a parent'.

20 Interview with Miki Moeketsi, by John Peffer and Mpho Mathebula, Phiri, 10 August 2014.

21 According to Khwezi Gule, then chief curator at the Soweto Museums, among the donors there were those who were now 'respectable' members of their communities and were worried that images seen in a video display on life in the late 1970s and early 1980s would show them in an unfavourable light, especially when seen partying in their youth. Interview with Khwezi Gule, Hector Pieterson Museum, Orlando West, 26 July 2012.

Interview with Miki Moeketsi, 10 August 2014. 
months without seeing her'. But in this picture they are together, looking smart. They were 'from church', he explained, 'and she was dressed very nice'. A message was sent to a neighbourhood photographer to have him pass by the house to document the occasion. He was looking good too, because when she came to visit 'she had bought some nice clothes' for him and he then 'had to wear them for a snap'. 'You could not know these things just from looking at the photo,' he said, and laughed. Mr Moeketsi never did show me that picture.

With the predominance of digital printing labs since the 1990s, there are new concerns. This is something I learned about during a presentation by students of the Market Photo Workshop who had conducted research among the street photographers around Joubert Park. ${ }^{23}$ If you go to Joubert Park in central Johannesburg today, you will find street photographers who will take your picture in front of a tree or a painted backdrop for a small fee. They mostly use digital cameras and print on site, though some go to a local colour lab for their prints. Apparently, customers sometimes become agitated when hearing that their prints will be made at one of the (as they referred to) 'Chinese-run' (but possibly Korean) colour labs in downtown Johannesburg. Customers are concerned that these colour labs might not throw away their original images, and might later 'do something' with them (they were not sure what), since strangers, especially foreigners, 'should not be holding onto pictures of you'. The owners of the photo development shops are well aware of this worry, as I subsequently heard from the owner of a PhotoFirst franchise in Empangeni when I asked him if customers often come to reprint from their older photographs. 'Yes,' I was told, but 'it is not cool to hold onto them. People don't like it.' When Mathebula and I asked to see copies of his older work from the 1980s, a local street photographer, also in Empangeni, was even more emphatic: 'I don't keep [the negatives]. They [the customers] would not want [that]. ${ }^{24}$

\section{Distributed Persons}

There was and still is an unambiguous context of trust between photographer and client, even a source of potential tension, and it merits closer attention precisely because it is often these very same so-called 'found' or 'orphan' pictures that show up for sale on the international art market today: those that were never retrieved, or were unable to be paid for, or remained in the photographer's archive a decade or so later. As we have seen in South Africa, it was common practice to shame customers who did not pay by hanging their portraits in the studio, and in her recent book Jennifer Bajorek states this was also common practice in West Africa. She speculates that these 'debtor pictures' may account for the West African 'vintage prints' sold overseas today. ${ }^{25}$ To me this indicates consent was never given, nor asked, before the later redistribution and sale of these pictures to strangers.

23 T. Sebyeng, M. Tshabalala and J. Gaegane, 'Contemporary Street Photographer Archives: Some Observations', presentation at 'Beyond the Iconic Image': A Workshop on Microhistory and Photography, University of the Witwatersrand, 14 June 2013.

24 Interview with Themba Mkhabela, by John Peffer and Mpho Mathebula, Ngwelezane, 18 May 2015.

J. Bajorek, Unfixed: Photography and Decolonial Imagination in West Africa (Durham: Duke University Press, 2020), 56-7. 
In his critique of recent publications and exhibitions of anonymous found snapshot photography, Geoffrey Batchen notes how 'chosen pictures are presented with a minimum of textual accompaniment ... like so many precious art objects. ${ }^{26} \mathrm{He}$ elaborates further that in these later anonymous presentations by strangers not 'privy' to the 'conversation' inherent in their making, that '[p]ersonal intimacy is replaced by voyeuristic speculation, thus making even the most formulaic image a thing of fascination ... [which] it is argued, restores the creative exchange between viewer and photograph that has otherwise been lost in the transfer from family archive to art book. ${ }^{27}$ Despite a select few being isolated and exhibited for their seeming exotic qualities, their 'freak factor', the great mass of family images floating about in the world are actually quite boring to those who are not in the pictures. Batchen notes this dual nature of other people's pictures: on the one hand they are dreadfully conventional, on the other they are capable of inducing a photographic experience that can be intensely individual, often emotional, sometimes even painful. ${ }^{28}$

Tina Campt, in her writing on African diaspora photographies in Germany and England, is uncomfortable, especially when referring to pictures created as family photographs, with the terms 'orphan works' and 'found' photography for images whose owners have not been located. ${ }^{29}$ She sees the terminology of orphanage as problematically emphasising abandonment and powerlessness over the kinds of agency inherent in such pictures - even in their possible later anonymity. Campt prefers instead to call them 'fugitive', because like fugitives they may be anonymous but still retain agency as 'interlopers' even while 'running away' from their supposed proper place. ${ }^{30}$ While I find her suggestion thought provoking, I think 'fugitive' with its connotation of being a runaway and possibly in need of assistance allows the author to speak for and about, through a series of projections and speculations, instead of alongside and with the subjects. I therefore prefer to use the term 'family photography', because it brings more directly to mind the dynamic aspirations and tensions that exist within families as well as the right to choose to not be looked at by the prying eyes of strangers. The term domesticates, it makes familiar, not the images themselves but their demand for opacity.

Marianne Hirsch reminds us that while in many ways family photographs merely enact visual conventions, 'They carry meaning within the family's own narrative and are emptied of that meaning outside that narrow circle. ${ }^{31}$ Despite a surface that makes them appear accessible or normalising, associations with personal and local experience outside the frame are not there for you when looking at others' pictures. And yet this does not change the fact that many wish their images to be kept private.

\footnotetext{
G. Batchen, 'Snapshots: Art History and the Ethnographic Turn', Photographies, 1, 2, 2008, 130.

Ibid., 132 .

Ibid., 133.

29 T. Campt, Image Matters: Archive, Photography, and the African Diaspora in Europe (Durham: Duke University Press, 2012). See also V. Williams, 'Lost Worlds', Eye Magazine, 55, 2005; K. Cross, 'The Lost of Found Photography', Photographies, 8, 1, 2015; and S. Habibi Minelli, 'Creation, Circulation and Use of Photographic Images: The Issues Surrounding Orphan Works and Their Educational Implications', Photographies, 2, 2, 2009.

30 Campt, Image Matters, 86-7.

31 M. Hirsch, The Familial Gaze (Hanover: University Press of New England, 1999), xiii.
} 
What others are allowed or not allowed to see or know about you goes to the heart of the concept of self-determination, and how the boundaries are expressed relates to what we call identity formation in the modern world. Julia Hirsch notes that family photography originally 'gained popularity' in Europe during 'a time of social and economic instability' in the nineteenth century. ${ }^{32}$ I also found in South Africa that having oneself portrayed as 'normal' or 'middle class' was not merely a replication or enactment of patriarchal structures, it was also an attempt to create an image of stability during a time of intense political and social turmoil. ${ }^{33}$ Batchen suggests that if we hope to consider these kinds of pictures and their particular histories seriously and on their own merits, 'This means looking more closely at the relationship of the snapshot to a network of expectations and obligations extending far outside the picture itself ... to consider the snapshot photograph as both a complex social device and a personal talisman, rather than as a static art object. ${ }^{34}$

Whether and under what conditions people are happy to share such images with strangers is an open question. In my experience the answer was 'sometimes, yes'. But how can you know? If I reprint images without asking what is outside the border of the picture, am I not dishonouring the social contract and turning away from my responsibility to the people in the image?

Referring to colonial and anthropological images, Elizabeth Edwards has written,

It was claimed by many peoples in the past that photographs captured the soul, drained the lifeblood, stole the shadow - concepts that have become powerful political metaphors in the present. And, of course, they were right. Photographs appropriated into Western archives for too many years did exactly that: they transferred from the subjects the power to tell about culture and history, diminishing cultural vibrancy to corrosive effect and transforming the historical particularities through which subjects are perceived. ${ }^{35}$

Erasure of subjectivity also takes place when family pictures are sold outside the communities they were produced for. The people in the pictures, about whose style the scholars and critics may say only positive things, have been stripped of their names and the complexities of their identities. They become generalities, they become projections, they cease being their own subjects and become other people's fungible objects. As the reprints or their white borders grow larger, and the artist's or foreign collector's name becomes more prominent, the subjectivity of the people in the image is erased at the margin. Likewise, the surrounding context that had once indicated they were used as family photos is whited out.

For Malick Sidibé and Seydou Keïta, the now internationally famous studio portraitists from Mali, their reprints are everywhere today but no one has

J. Hirsch, Family Photographs: Content, Meaning and Effect (New York: Oxford University Press, 1981), 42.

3 J. Peffer, 'Vernacular Recollections and Popular Photography in South Africa', in C. Morton and D. Newbury (eds), The African Photographic Archive (London: Bloomsbury, 2015).

34 Batchen, 'Snapshots', 133.

35 E. Edwards, 'Notes from the Field: Appropriation', The Art Bulletin, 94, 2, 2012, 172. 
systematically asked the subjects themselves about their views or for their permission. Candace Keller, whose own 'Archive of Malian Photography' project is laudable for its consideration of local sensibilities and professional ethics, notes in a recent essay that, 'although Sidibé argues that most clients are honored to find their images reproduced in catalogues and exhibitions, he admits others have suffered humiliation and vehemently criticise the practice. ${ }^{36}$ She mentions a gallery in Paris where Sidibés 1970s negatives were being reprinted and sold without consent of the subjects, where a woman from Bamako was outraged to find a huge blown-up image of her (now much more conservative) mother scantily clad. Consider also Manthia Diawara's remark: 'in [1960s] Mali, young women were not allowed to be seen by their parents dressed the way they were in this photo. Such conduct would have been deemed indecent by Islam. ${ }^{37}$

The context of the image in the photograph is important, but so is the context of the distribution of its copies. ${ }^{38}$ While it is commonplace for writers on photography to refer to replication and dispersal as characteristics of the medium, I find this is overrated because the ability to make innumerable identical copies of the same picture and to distribute these everywhere at once was in fact not characteristic of photography in its earliest manifestations. The daguerreotype was a one-off process and most photographs that achieved mass circulation did so via reproduction in another medium, namely through etching and engraving, for much of the nineteenth century and via the halftone process after $1880 .{ }^{39}$ By the 1860 s albumen prints in carte-de-visite format of famous personalities were widely reproduced, circulated, and collected but by definition persons who were not famous did not usually find their faces distributed in this way - unless they were made into ethnographic specimens or exoticised as curiosities.

In South Africa, as is true of family photography elsewhere in the world, it is also not correct to assume there were innumerable copies of images made. More often the camera was used for its ability to record, for its realism and for its ability to enhance the image of the subject, to make them come out good. Its ability to make numerous copies was not so important, or at least we can say it was not much taken advantage of. In fact, this reproducibility aspect could be mistrusted, a source of anxiety for the reasons already given above. In the townships, most people I spoke with only ever had one, perhaps two or maybe three copies at most, made from any image of themselves. Most often people had snaps made just 'for themselves', for instance to celebrate a holiday occasion or visit to the beach or to document a sharp outfit, and they only ever had one print made..$^{40}$ 45 .

37 M. Diawara, 'The Sixties in Bamako: Malick Sidibé and James Brown', Paper Series on the Arts, Culture, and Society, 11 (New York: Andy Warhol Foundation for the Visual Arts, 2001), 4.

38 On issues of circulation in photography studies, see T. Phu and M. Brower, 'Editorial', History of Photography, 32 , 2, 2008.

39 G. Batchen, 'Double Displacement: Photography and Dissemination', in T. Gervais (ed), The 'Public' Life of Photographs (Toronto: RIC Books, 2016).

40 Peffer, 'Vernacular Recollections', 119. Some studios held onto negatives in the hopes of return business, but the photographers I spoke with told me that even frequent customers rarely asked for copy prints later. 
Some photographers would make two or three copies and sell these at a group price. The uses of these few copies differed, though all had to do with some form of constructing a network of familiars via selective distribution. Some common examples include young men and women engaged in courtship who would trade pictures; close male or female friends who had their snap taken together who would then each get one copy and sometimes another to give to a lover or parent; sisters-in-law, omakoti, women related through marriage into the same family would often gift snaps of each other; relatives in the city would send studio photos to family in the country and vice versa; extended families with members in Cape Town, Port Elizabeth, Durban and other cities would maintain ties by exchanging photographs of themselves on holidays and other occasions. Of course, only those who could be trusted, those who were family or close friends, would be given a copy. Perhaps visitors would be shown certain pictures on special occasions, but they certainly would not be allowed to walk away with them or make copies for their own use. When a parent passes away their collections of images, like the rest of their property, are distributed among siblings and children along customary lines of succession. ${ }^{41}$ In this way the images themselves, as well as their distribution networks, helped define personal networks and helped affirm the relationships and the boundaries that defined families and selves. ${ }^{42}$

This aligns with what Edwards has found generally, that 'photographs are not merely a result of social relations but active within them, maintaining, reproducing and articulating shifting relations. ${ }^{43}$ She suggests further, following Alfred Gell, that as relational objects, 'photographs distribute personhood "beyond the bodyboundary"'. ${ }^{4}$ The implication is that family photographs are like parts of oneself that are allowed, with caution, to be shared with others and that this consensual sharing within familiar networks also helps constitute the persona by creating individual and corporate identities, and self-definitions of subjectivity.

Photographs-as-social relations are not just things to be collected or gifted, they are not just things to be regarded or to give visual pleasure - though surely they do these things. They also stand for the pleasure of representation of the self on one's own terms and the pleasure of membership in a network. Seen as relational objects and as extensions of personae they stand for the existence of the fuller personhood of individuals and are worthy of acknowledgement and respect, as heard in the traditional isiZulu greeting: siyakubona/sawubona - 'we see/recognise/give respect to you'.

Along these lines, I think that Ariella Azoulay's term the 'civil contract of photography' (which she usually applies to images that are more literally traumatic on their surface) may also be useful (with some modification) in the context of family

41 This was explained to Mpho Mathebula and me as we were examining heirloom photographs of the parents of his neighbour, Maria Makhanya, in Phiri, 1 February 2013. For comparison with Kenyan examples, see Behrend, 'Celebrating Life', 92.

42 See also P. Bourdieu, Photography: A Middle-brow Art, S. Whiteside (trans.) (Stanford: Stanford University Press, 1990), 19-31.

43 E. Edwards, 'Photographs as Relational Objects', published online in 2016 by Staatliche Akademie der Bildenden Künste Stuttgart, http://dakar-bamako-photo.eu/en/elizabeth-edwards.html, 5. Edwards elaborates from A. Gell, Art and Agency: An Anthropological Theory (Oxford: Oxford University Press, 1998); and B. Smith, 'Images, Selves and the Visual Record: Photography and Ethnographic Complexity in Central Cape York Peninsula', Social Analysis, 47, 3, 2003.

Edwards, 'Photographs as Relational Objects', 8. 
photography, so that we may attempt, as Azoulay does, 'to anchor spectatorship in civic duty toward the photographed persons who haven't stopped being "there," toward dispossessed citizens who, in turn, enable the rethinking of the concept and practice of citizenship. ${ }^{45}$ To refer to any photography as a civil contract is to ask of the viewer that they recognise the dignity of the depicted, and to not project facile empathy, shame, pity, or compassion: 'They [the photographs] call on me [the hypothetical future viewer] to recognise and restore their citizenship through my viewing. ${ }^{36}$

Family photographs ask even more of us: that we also respect that they were made to create the private domain, that space for personal and cohort experimentation that includes aspects of play and crisis and belongs out of full public view. Our civil contract should include respect for people's right not to be looked at. Drawing inspiration from Irwin Altman's social psychological definition of privacy as 'a central regulatory process by which a person (or group) makes himself more or less accessible and open to others' ${ }^{47}$ legal scholar Julie Cohen reframes privacy as 'preserving room for socially situated processes of boundary management to operate. ${ }^{48}$ As Cohen sees it, 'our understandings of selfhood are shaped by the embodied habits of boundary management that we develop."9 Where Altman's primary concern was with concepts of personal space, and Cohen's writing applies this to problems of identity and surveillance in the digital realm, I see this definition of privacy as applicable to the kinds of family photography we are discussing here as well.

Privacy, in this view, is not just a kind of negative refusal of public engagement. Privacy entails, rather, a positive and dynamic form of choosing where, when, and how to engage the self or one's indicia within the public sphere, in a dual sense. First, at the site of creation where self-images were made, people tried on and modelled clothing styles and poses, in camera. In that quasi-public changing room of modernity subjects styled themselves in studio snaps for self-use or for distribution to kin and familiars. ${ }^{50}$ Second, there is the refusal of distribution of these pictures outside their intended networks, where strangers might peek into the dressing room without consent. Cohen writes that ' $[\mathrm{t}]$ he social and material practices that express selfhood also supply situated users with important information about the nature of both selfhood and privacy. ${ }^{51}$ Referring to Foucault's concept of 'technologies of the self', she elaborates:

Practices of self-improvement are diverse, ranging from reading to fashion and grooming to diet and exercise. Some of these practices are undertaken

\footnotetext{
45 A. Azoulay, The Civil Contract of Photography (New York: Zone Books, 2008), 16-17.

46 Ibid.

47 I. Altman, The Environment and Social Behavior: Privacy, Personal Space, Territory, Crowding (Monterey: Brooks/Cole Publishing, 1975), 3; J. Cohen, Configuring the Networked Self: Law, Code, and the Play of Everyday Practice (New Haven: Yale University Press, 2012), 131.

48 Cohen, Configuring the Networked Self, 148.

49 Ibid., 131.

50 M. Diawara, 'Talk of the Town: Seydou Keïta', Artforum, February 1998.

51 Cohen, Configuring the Networked Self, 132.
} 
in public and others in private; even private practices of self-improvement, however, reshape the self for an imagined audience. Shared assumptions about which practices belong where inform collective notions of how selfhood is best fulfilled and how privacy is appropriately asserted. ${ }^{52}$

This brings us to the possibility of ownership of the outward likeness of the self as a species of private property, and therefore to complex issues of legal copyright and privacy rights and of what has constituted an 'identity' in the public sphere in the previous century and today. It indicates, too, that thinking from the South, as we are here, is critical work. It calls for a more inclusive global history of photography. It calls for action against a global neoliberal economy that continues to subordinate and commoditise Black bodies through their images. It highlights how exploratory self-image making, and distribution network making, are integral to self-directed processes of identity formation. The private room to play and room to change is deserving of respect and protection. ${ }^{53}$

\section{Copyright and Privacy}

While it does not clear up all moral and ethical questions, it is worth noting that in South Africa the Copyright Act (1978) is on the side of the photographed subject since it establishes that the person who commissions a photograph owns its copyright. ${ }^{54}$ No formal registration by the owner is required for these rules of copyright to apply. ${ }^{55}$ Unless an explicit written contract stating otherwise has been drawn up, the rule is that pictures taken at a portrait studio are owned by the person in the picture if they are the one who had it made to order, which was almost always the case. This right over reproduction, distribution, broadcast, and sale extends to fifty years if and when the owner has consented to make it public. Exceptions include scholarly and other fair use, but not reproduction by others for exhibition or monetary gain. ${ }^{56}$

Even if the customer fails to pay, the South African Copyright Act, like the British Act of 1911 on which it was modelled, states that they still retain copyright:

Where a person commissions the taking of a photograph, the painting or drawing of a portrait, the making of a gravure ... and pays or agrees to pay for it in money or money's worth, and the work is made in pursuance of that commission, such person shall ... be the owner of the copyright ... the person who commissions the work is the owner of the copyright ...

\footnotetext{
52 Ibid.; M. Foucault, 'Technologies of the Self', in L.H. Martin, H. Gutman and P.H. Hutton (eds), Technologies of the Self: A Seminar with Michel Foucault (Amherst: University of Massachusetts Press, 1988).

53 The opacity of ourselves to ourselves is as critical as the opacity of the other: 'there are places where my identity is obscure to me, and the fact that it amazes me does not mean I relinquish it.' Glissant, The Poetics of Relation, 192.

54 South African Copyright Act (98 of 1978, as amended up to Copyright Amendment Act 2002).

55 D. Milo and P. Stein, A Practical Guide to Media Law (Durban: LexisNexis South Africa, 2013), 149.

56 South African Copyright Act, section 21(1)(c).

Ibid., emphasis added.
} 
It is pictures 'left behind' like this that are now circulating in the art market, such as the images made at 'Bobson' studio of Durban and 'Kitty' studio of Pietermaritzburg that have been extensively exhibited overseas in recent years. As you read this, whatever your own personal feelings about so-called 'orphan images' may be, it remains the case that in the current art market the rights of South African subjects over copyright of their own pictures and the corresponding rights to proceeds from their sale have not been honoured. One obvious question is: Why is this allowed to continue? One likely answer is that bringing suit in court can be expensive, and art dealers, auction houses, and collectors overseas appear to be taking advantage of the fact that the legal owners are likely relatively poor and unaware their faces are being monetised in this way and therefore are unable to do much about it.

What about 'snapshots'? It is important to know that in South Africa the vast majority of pictures referred to colloquially as 'snaps' were in fact created 'for hire'. In the townships few families had cameras at home until the rise of cell phones with cameras in the 2000s. This means that even those pictures that to an overseas viewer might look like instamatic camera informal snapshot pictures were in fact more formal affairs, and they were usually made by local professionals or semi-professionals who roamed the neighbourhoods and worked for hire. But if a neighbourhood photographer in Soweto was invited to photograph a gathering or even just to take a picture of you in a nice suit standing in front of your home, then you still retained the copyright to your image. It does not matter whether it is aesthetically a more formal type of portrait or a less formal snap or kiekie..$^{58}$

When I asked Soweto cameraman Glory Ndlazi about copyright, he brought out his own AGFA Camera Club brochures from the 1990s. It was from these, he said, that he had learned the details of how photographers should draw up signed release forms with their clients so that they, the photographers, could gain reproduction rights over the pictures they took. But drawing up contracts with customers is only a recent development of his practice and those of his photographer colleagues, he claimed. ${ }^{59}$ Elsewhere in my research I did not find any photographers or customers who remembered paper contracts or statements of consent. Only a basic monetary receipt or order was drawn up, if anything. Beyond the text of the law itself, and the evidence that photographers (at least in certain circles like camera clubs and popular photography magazine readers) were made aware of the law, there was a general understanding between subjects and portrait photographers, going at least back to the 1950s and most likely earlier. It was understood that the subject's permission was needed if the photographer wanted to do anything with their pictures besides hand them to the customer. ${ }^{60}$

60 In South African common law, there are also rights of privacy and personality that apply to family photography, and these include protections for individuals against improper uses of their images beyond the property aspects encoded in the Copyright Act. 
For studio photography or other kinds of photography for hire in South Africa, the photographer does retain what are termed 'moral rights', meaning they must be credited as the 'author' or creator of the work. This includes the right to be named when the work is published, exhibited, or sold and the right to forbid any alteration of the integrity of the look or style or contents of the work, without consent. But ownership of the image is retained by the one who commissioned the image, and almost always this is the subject depicted in the photograph. 'Ownership' includes the right to copy, sell, or make available to the public. This statutory split between the author and the owner is in some senses unique to South Africa; it is a relic from an earlier era and it differs from how artists' rights are apportioned in other countries in current law today. But for the reasons outlined in this essay I think the South African model is fortuitous and valuable as an example for international rights over images in the twenty-first century.

\section{Best Practices}

As family photography from Africa is being snatched up by the art world, I think it is time that we (scholars, curators, collectors, art dealers) decisively move beyond the spectacle of (art world) 'discovery' and 'salvage', in order to place questions of how to work with the subjects depicted at the front of our practice and our discourse. This is even more urgent now, since the fates of personal images have been thrown into further crisis as they have become commoditised in the digital age. A decade from now will we yet again have to ignite a debate around 'Restitution of African Cultural Heritage', as Felwine Sarr and Bénédicte Savoy have recently done in their report for the French government, but this time about Africa's photographic heritage? I was not involved in the production of their report, but an essay I published in Third Text in 2005, titled 'Africa's Diasporas of Images', is cited by Sarr and Savoy as having informed their analysis. ${ }^{61}$ Therefore I feel compelled to comment. The first half of my 2005 essay suggested ways to write a more ethical kind of history of traditional African art, as a dissemination (a 'diaspora') of objects and images inflected by successive experiences of hybridity and trauma. The second half, not cited by Sarr and Savoy, examines the erasure of subjectivity resulting from the then relatively young market in African portrait photography abroad. I believe the issues are related, and given the current excitement around restitution I think we should also be discussing how to prevent control over this photographic heritage and over its discourse from being lost to the West, this time before it is too late. In terms of circulation through the art market, following basic rules of consent already found in copyright and privacy law would be a good start.

61 F. Sarr and B. Savoy, No. 2018-26, Restituer le Patrimoine africain. Vers une nouvelle éthique relationnelle, Rapport remis au Président de la République, Emmanuel Macron, le 23 novembre 2018, 25; J. Peffer, 'Africa’s Diasporas of Images', Third Text, 19, $4,2005$. 
As for scholarly work, fair-use exclusions may apply; nevertheless, an even higher ethical standard is expected. Examples of inspiring models for subject-oriented approaches to research on family uses of photography may be found in the work of anthropologists Liam Buckley (The Gambia), Richard Vokes (Uganda), and Heike Behrend (Kenya). ${ }^{62}$ Behrend's chapter on wedding photography among Muslims in Mombasa and Lamu is of particular interest since respecting local image prohibitions meant she was prevented from illustrating the photographs she describes in the text. She relies instead on verbal description, in keeping with conservative Islamic tradition, and includes a remarkable series of images of wedding stages - but with no people in them. This allows the reader to see the conventional setting and decor without violating the conservative image prohibition against individual women of the family being seen by outsiders. This tactic further highlights what cannot be seen in a way that supersedes the verbal description while honouring the wishes of the photographic subjects.

Placing depicted subjects at the centre of a research project instead of starting with an 'archive' of found photos or with 'the artist' is important work, and it is difficult work. Even though the studio portrait images he reproduced for The Black Photo Album are dated mostly from the early twentieth century, and thus were beyond copyright, Santu Mofokeng clearly states that all were used with permission of the nine families whose pictures are included.$^{63} \mathrm{He}$ confided to me, further, in 2013 that most of the images he used had been located via a close network of friends, neighbours, and extended family. ${ }^{64}$ That is to say, the people displayed in The Black Photo Album were not abject strangers, they were of his own personal network, his familiars. Mofokeng also spoke of the difficulty of engaging with these historical photos that at first seemed so foreign to his experience, and how this was something he used the project to work through for himself. ${ }^{65}$ Pursuing research into family collections is difficult, too, because over time families become dispersed over great distances, or cease speaking to one another. ${ }^{66}$ 'They belong and circulate in the private domain,' Mofokeng wrote, and 'their significance lies outside of the framed image. ${ }^{67}$ And this includes the often painful process of engaging with the past through strategies of postmemory today, with its aspects of embarrassment, denial, or structured forgetting resurfaced and examined, as The Black Photo Album does.

And there is Lindokuhle Sobekwa's series 'I carry Her photo with Me' (2017-) which seeks to excavate, and recreate, a mythology for the life his sister Ziyanda, who disappeared when he was a young boy and whose face was cut out of the family snaps. Sobekwa is looking for traces of his lost sister in family photos and by creating

62 H. Behrend, Contesting Visibility: Photographic Practices on the East African Coast (Bielfeld: Transcript Verlag, 2013); L. Buckley, 'Self and Accessory in Gambian Studio Photography', Visual Anthropology Review, 16, 2, 2000; R. Vokes, 'On "the Ultimate Patronage Machine": Photography and Substantial Relations in Rural South-Western Uganda', in R. Vokes (ed), Photography in Africa: Ethnographic Perspectives (Woodbridge: James Currey, 2012).

63 S. Mofokeng, 'The Black Photo Album/Look at Me: 1890-1900s', Nka Journal of Contemporary African Art, 4, Spring $1996,56$.

64 Interview with Santu Mofokeng, Bez Valley, 25 January 2013.

65 C. Diserens (ed), Chasing Shadows: Santu Mofokeng, Thirty Years of Photographic Essays (New York: Prestel, 2011), 13.

66 Ibid., 15.

67 Mofokeng, 'The Black Photo Album', 54. 
a photographic scrapbook diary of things like 'the places she lingered', people she had known, and her clothing hanging on a line in an empty back yard. ${ }^{68}$ The effect of these projects is to create more mystery, not less, to leave space for opacity in the service of self-knowing.

These examples hint that, contrary to worries that respecting privacy might create a chilling effect, there are innovative ways to show and rethink family photographs while honouring the dignity of their subjects. Thinking opacity is a strategy for better understanding lived experience, just as practising refusal is a strategy for insisting on the private sphere and for resisting inequity.

Today, in addition to the art market, privacy and self-image ownership are increasingly at risk as people upload 'found' photos to the internet where face recognition technology is able to tag them. In a moving essay published in 2016 in The New York Times Magazine, titled 'The Digital Afterlife of Lost Family Photos', Teju Cole expresses his aversion to such practices, especially when done to people of colour, since databases and tags 'can wind up being hostile toward communities of color'.69 Even if - or perhaps because - the photos were 'found at a flea market' or at some point tossed in the trash, people often want their images posted by others to be removed from online fora. Cole tells of one Mr Lee, an avid collector of 'found' photographs of Black subjects, who, after posting found photos to Facebook was contacted by one of the subjects who had been tagged by Facebook's face recognition function, asking him to 'take down' the pictures. Lee 'realised' from this encounter how, 'The black body is used as a commodity, as something that is surveilled. The man was telling me, "No, you're not welcome, this is not art, get the hell out of our lives"' Cole writes that 'Black people in particular, against the historical backdrop of surveillance and state hostility and corporate disregard, have a right to doubt these technologies.70 He concludes that for 'all of us, but especially for those in communities of color, being digitally tracked does not solve the conundrums of inequality. Whatever else the machines learn, they'll have to learn about our sense of privacy too, the human sense of leaving some things left untagged and undeclared'. ${ }^{71}$

'The "private life", says Roland Barthes in Camera Lucida, 'is nothing but that zone of space, of time, where I am not an image, an object. It is my political right to be a subject which I must protect. ${ }^{72}$ This is a text where the author quite purposefully held back the very picture of his own mother that he reveals is the primary reason for the writing itself. He does not show this picture because it is too painful for him and, in any case, he does not think it would interest the reader who knows little of its context. This is not where I thought my interest in studying reception would lead me: to a litany of refusal. It is a dilemma of conscience that is already familiar to those doing

72 R. Barthes, Camera Lucida: Reflections on Photography, R. Howard (trans.) (New York: Noonday Press, 1981), 15, emphasis in original. 
research in other communities than their own. What you seek to know is the insides of things, what you do not already know, what is hidden from view. But once you are inside a bit more, once you have been welcomed into the family, then you become a member and responsible, too, regarding the family secrets.

If the photograph is family, treat it like family.

If you decide to take an activist approach and reveal some secrets in order to produce counter-memory against structured forgetting, that would mean to self-consciously, and with caution, go against the wishes of the family. That is another story. 